Sports Coaching

\title{
Strategies adopted in the defensive return by handball coaches from teams U-12 to U-18
}

\author{
Ana Laura Bento ${ }^{1}$ (1) , João Paulo Torres di Gilio ${ }^{1}$ (i) , Rafael Pombo Menezes ${ }^{1}$ \\ ${ }^{1}$ Universidade de São Paulo, Escola de Educação Física e Esporte de Ribeirão Preto, Ribeirão Preto, São Paulo, Brasil. \\ Associate Editor: Angelina Zanesco. UNESP/Rio Claro, SP, Brazil
}

\begin{abstract}
- aims: to analyze the choices of handball coaches for structuring the defensive return throughout the teaching-learning process (U-12 to U-18 teams). Methods: Nineteen coaches from teams U-12 to U-18 from two leagues in the state of São Paulo were interviewed. The speeches from the semi-structured interviews were analyzed through thematic analysis, which produced two themes and their respective subthemes. Results: Most coaches structure their defensive return and emphasize content to make it difficult for an opponent to counterattack. A higher percentage of directed play was observed in teams U-12 and U-14, which suggests a possible early specialization process. In the U-16 and U-18 teams, higher percentages of free play were observed when compared to the others. In older teams, a higher percentage of directed play would be expected, mainly because these are stages with an increase in player specialization. Conclusion: The findings suggest that the simultaneous training of different teams may be leading to sports specialization procedures in the younger teams and, simultaneously, underestimating the possibilities in the older teams.
\end{abstract}

Keywords: youth sport; team sport; teaching-learning; coaching.

\section{Introduction}

Handball is a complex team sport, with an internal $\operatorname{logic}^{1}$ that requires teams to self-organize according to the phases of the game (attack, defensive return, defense, offensive transition) ${ }^{2,3}$. The principles and rules of action in each phase of the game $e^{2,4}$ assist in the elaboration of the game model of each team and the strategic-tactical-technical evaluation process ${ }^{5}$.

The transition phases are decisive for a good performance in handball ${ }^{6-9}$, and the fast break has been used as an important strategy of the offensive transition ${ }^{2,4}$ to score ${ }^{7}$. The fast break is divided into phases, with a different number of players trying to explore spaces not occupied by an unstructured defense $\mathrm{e}^{3,6,8}$. In contrast, the defensive return presents principles opposed to the offensive transition to protect the sectors at greatest risk and to organize the defensive system ${ }^{4,10-12}$. In the case of the German elite teams, the defensive return shows relevant, because this phase requires players who can take split-second decisions?.

Handball learning occurs throughout the player's development process, in which early sports specialization processes must be avoided ${ }^{13}$. The Developmental Model of Sports Participation (DMSP $)^{14}$ describes different sports trajectories and stages for sports training (sampling, specialization, and investment). Specifically, in the handball context, some long-term training proposals have been developed ${ }^{12,15-17}$, which highlight the importance of diversification in the initial stages (with general and specific knowledge) and the gradual approach (over time) with the adult game (warning about the problems of specializing early).

The proposals of the aforementioned authors highlight the teaching of different elements relevant to each stage of the game (offensive, defensive, and transitions), which are related to the important antagonism between the principles of action (keep/recover the ball, progress/impede progression, score/protect own goal) $)^{2}$. Specifically, in the defensive transition, the players manifest different tactical intentions ${ }^{17}$ that depend on the proximity to the ball ${ }^{18}$.

The concepts of free play and directed play ${ }^{19,20}$ adopted by the handball teams dialogue with the process of sports specialization in that sport. It is noticed that the concept of free play is important for the U-12 and U-14 teams as it promotes an environment that favors the development of individual tactical intentions aligned with the game principles ${ }^{19}$. The concept of directed play is the most practiced and guides the team's collective activity, valuing the tactical aspects that develop according to the pre-coordinated collective objectives ${ }^{19}$. Although these concepts were formulated to characterize offensive actions ${ }^{19,20}$, approximations with the defensive return are possible, especially when we consider 1) the need to adapt the position of defenders concerning the different attackers who can start a counter attack and 2) the occupation of predetermined regions of the court.

Several studies in handball have analyzed the offensive transition (especially fast breaks), and generally use official match statistics (with quantitative analysis) ${ }^{7,8}$. There is a lack of studies on defensive returns, and our study addresses this topic based on the coaches' speeches, using a qualitative method of analysis. Finally, some systematic reviews ${ }^{21-23}$ show the predominance of analyzes by professional teams and the research gap with youth teams. This gap was also addressed in our study.

In this sense, this study aimed to analyze the choices of handball coaches for structuring the defensive return throughout the teaching-learning process. 


\section{Methods}

\section{Participants}

Nineteen coaches from the U-12, U-14, U-16, and U-18 male and female teams participated in this research, which competed in two handball leagues in the state of São Paulo. All coaches signed the Free and Informed Consent Term approved by an Ethics in Research Committee (CAAE: 39796814.8.0000.5659). The characteristics of the participants are shown in Table 1.

Table 1 reveals the heterogeneity of the interviewed group, with some coaches coaching several teams of both genders, and others coaching only one team. This factor reveals that handball develops in multiple scenarios.

Table 1 - Coaches characteristics

\begin{tabular}{|c|c|c|c|}
\hline Coach & Age & Teams & Experience as coach (years) \\
\hline S1A & 46 & $\begin{array}{l}\text { Male: U-14, U-16, U-18 } \\
\text { Female: U-12, U-14 }\end{array}$ & 21 \\
\hline $\mathrm{S} 1 \mathrm{~F}$ & 41 & Female: U-16 & 20 \\
\hline S1M & 29 & Male: U-12, U-14, U-16, U-18 & 08 \\
\hline $\mathrm{S} 2 \mathrm{~A}$ & 55 & All (male and female) & 24 \\
\hline $\mathrm{S} 2 \mathrm{~F}$ & 45 & Female: U-16, U-18 & 18 \\
\hline $\mathrm{S} 2 \mathrm{M}$ & 38 & $\begin{array}{l}\text { Male: U-12, U-14, U-16, U-18 } \\
\text { Female: U-14, U-16, U-18 }\end{array}$ & 05 \\
\hline $\mathrm{S} 3 \mathrm{~A}$ & 54 & Male: U-12, U-14, U-16, U-18 & 23 \\
\hline S3F & 26 & Female: U-12, U-14 & 03 \\
\hline $\mathrm{S} 3 \mathrm{M}$ & 31 & Male: U-16 & 10 \\
\hline S4A & 44 & All (male and female) & 21 \\
\hline S4F & 40 & Female: U-14 & 20 \\
\hline S4M & 34 & Male: U-12 & 04 \\
\hline S5A & 53 & $\begin{array}{c}\text { Male: U-12, U-14, U-16 } \\
\text { Female: U-12 }\end{array}$ & 28 \\
\hline S5F & 34 & Female: U-14 & 15 \\
\hline $\mathrm{S} 5 \mathrm{M}$ & 26 & Male: U-14, U-16 & 05 \\
\hline S6A & 39 & $\begin{array}{l}\text { Male: U-16 } \\
\text { Female: U-16, U-18 }\end{array}$ & 15 \\
\hline S6F & 35 & Female: U-16 & 11 \\
\hline S6M & 45 & Male: U-18 & 14 \\
\hline \multirow[t]{2}{*}{ S7F } & 36 & Female: U-18 & 14 \\
\hline & $\begin{array}{l}\text { Mean: } 39,5 \pm 8,8 \text { years. } \\
\quad(\min =26 ; \max =55)\end{array}$ & $\begin{array}{l}\quad 57 \text { teams } \\
\text { Male: U-12=7; U-14=8; U-16=10; U-18=7 } \\
\text { Female: U-12=5; U-14=7; U-16=7; U-18=6 }\end{array}$ & $\begin{array}{l}\text { Mean: } 14,7 \pm 7,5 \text { years } \\
\quad(\min =3 ; \max =28)\end{array}$ \\
\hline
\end{tabular}

\section{Interviews and speeches analysis}

Due to the descriptive nature of the information, a qualitative research approach was chosen, through semi-structured interviews. This type of interview has open and flexible questions, aimed at understanding the context revealed by the coaches and the possibilities of new questions during their progress ${ }^{24}$. The main interest was based on the coaches' discourse on technical-tactical aspects related to the defensive return in handball. The interview consisted of two blocks: 1) personal information (to identify aspects such as professional performance and experience as a coach); 2) defensive return (technical-tactical aspects and organization).

The speeches were analyzed through thematic analysis prioritizing specific aspects in a deductive, latent, and constructionist way $^{25,26}$. This choice occurred due to the flexibility and usefulness of this method to provide a detailed analysis of the information ${ }^{25-27}$, based on six phases: 1) familiarization with the data; 2) coding; 3) searching for themes; 4) reviewing themes; 5) defining and naming themes; 6) writing up ${ }^{25,26}$. Finally, a thematic map was created to show the path of the coaches' strategic-tactical choices.

\section{Results}

Through thematic analysis, two main themes were produced: 'directed play' and 'free play'. Figure 1 shows the identified themes and relationships with each stage. 


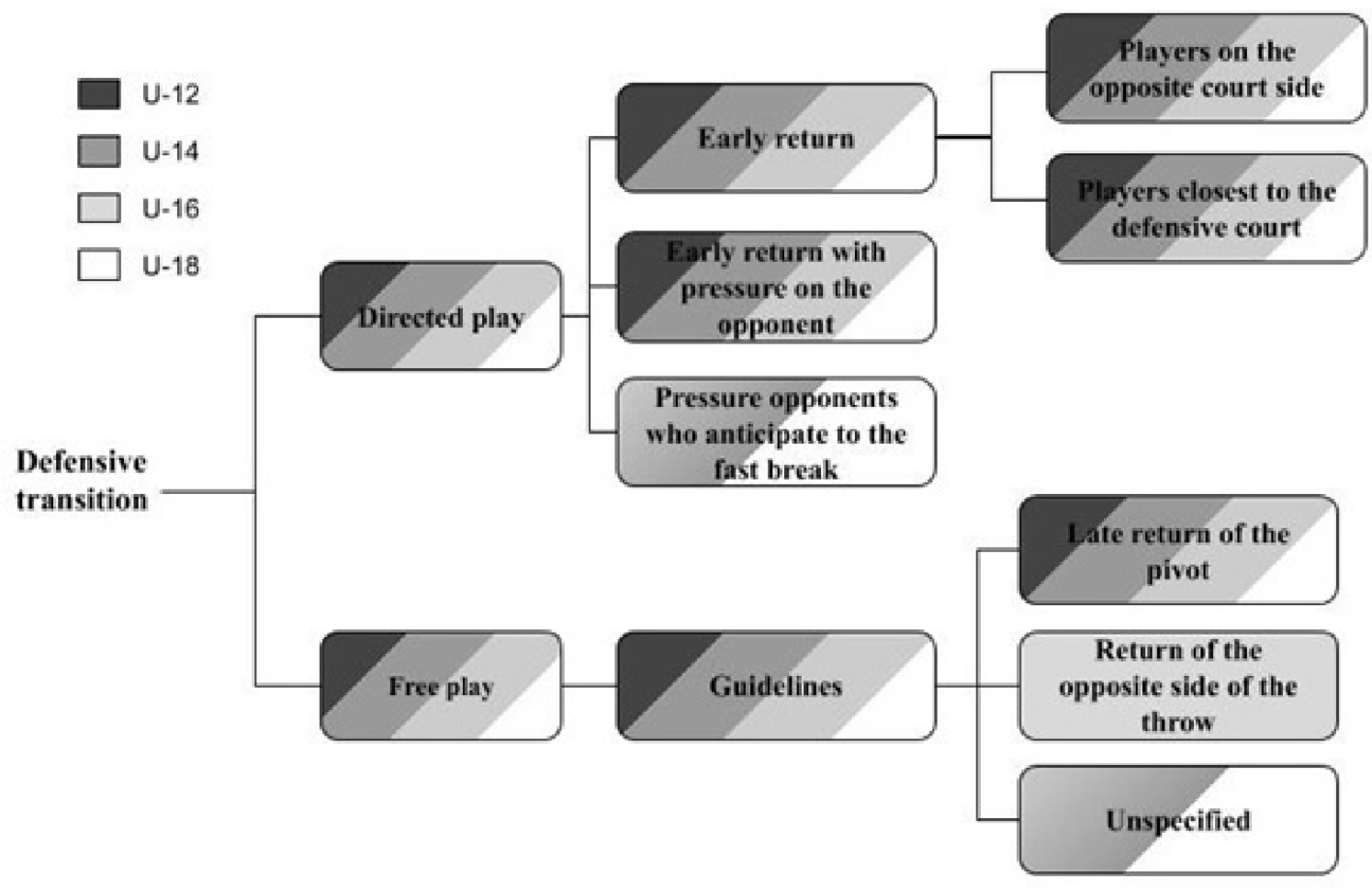

Figure 1 - Thematic map of defensive return structures

Theme 1 refers to the defensive return that occurs in the form of a directed play, with strategic principles defined by the coaches. According to the speeches presented below, three structures were identified for the defensive return: early return (S5F and S1A), early return with pressure on the opponent (S4M), and pressure opponents who anticipate the fast break $(\mathrm{S} 2 \mathrm{~F})$.

"We charge a lot for timing, to identify the throw situation, generally [the players from] the opposite side are returning, covering some situations" (S5F). "Perhaps the main ideas are defensive balance, the back players closest to their defensive court have to return first looking for that balance" (S1A).

"I usually structure it. For example, he loses the ball on one side, through the wing player, the opposite side is the first to return. [...] We interrupt many fast breaks just letting the player get in the way of the ball" (S4M).

"We are very concerned with defensive return... returning to take those who are ahead in the attack; if the opponent starts the fast break, the defensive return has to be on top of those who are in the fast break and those who are ahead" (S2F).

According to the themes built, the early return is organized by the coaches with the players returning to their defensive court at the moment of the throw, which can occur for the players on the opposite side of the throw and the players closest to the defensive court (Figure 1). In the early return with pressure, the attackers' return is similar to the one mentioned above, however, the coaches advise the players who have not returned to press the opponents' ball out. The coaches also mention the pressure on opponents who are anticipating the fast break, to unbalance the opponent's offensive transition.

In the opposite direction, Theme 2 encompassed the defensive return in a free play format, in which coaches establish guidelines (even without structuring) such as the late return of the pivot (S1M), the return of the opposite side to the throw (S2M) and without specifying the guidelines (unspecified - S6M).

“It still doesn't have [structure], in parts. Usually, we talk to them and leave the pivot or the central defender, both in the individual who defends further down, the one in the center of defense 6:0, 3:3, 5:1 (S1M)".

"It doesn't [structure the defensive return]. Not yet. I talk to them and say: if you shoot and you didn't score the goal, or you lose the ball, if it's on the right side, the left side quickly returns, which are wing player and back player [...] (S2M)".

"You lost the ball, you have to return, the first thing is to return to where you are closest because we need to have a defender there [...]. So the first thing is to return, then get organized (S6M)".

After elaborating the themes and sub-themes, the frequency of the possibilities mentioned by the coaches to structure the defensive return of the U-12 to U-18 teams was analyzed. In this analysis, the sub-themes were grouped into a) directed play (through early return), b) directed play based on opponents (through early return with pressure, and pressure on attackers who anticipate to fast break) and c) free play (with the sub-theme of the same name) (Figure 2). 


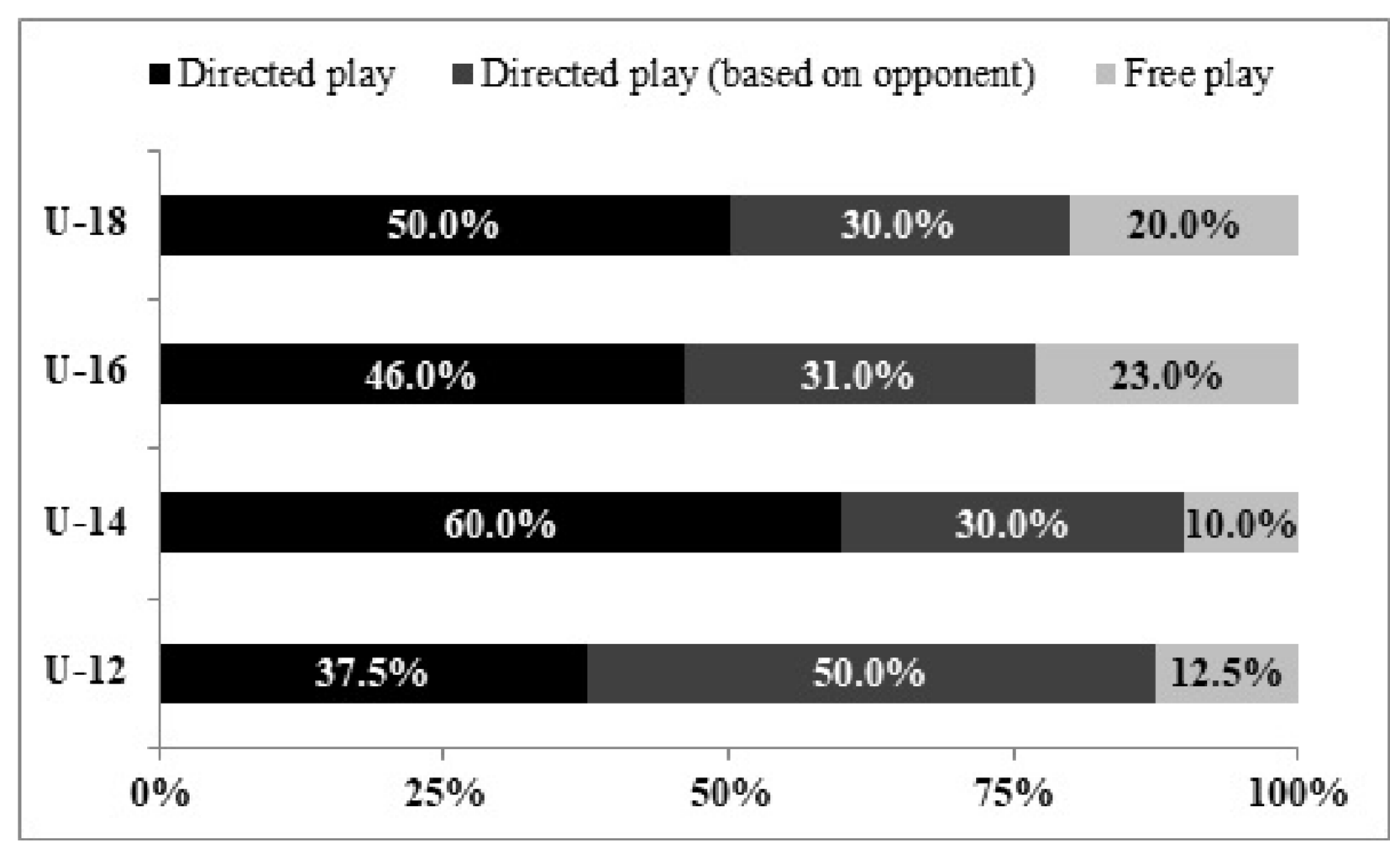

Figure 2 - Percentage of defensive return structures identified in the different stages

Figure 2 revealed that in the U-14, U-16, and U-18 teams there is a predominance of the directed play, while in the U-12 teams the directed play is based on the opponents predominates. Free play for defensive return was prevalent in U-16 and U-18 teams ${ }^{28}$. Some speeches were repeated in different teams because most coaches coach two or more teams and/or have different teams training

\section{Discussion}

This study aimed to analyze the coaches' choices about structuring the defensive return throughout the teaching-learning process in handball. The coaches opted for different strategies for the directed play (Theme 1) and the free play (Theme 2). Considering fast break as a relevant strategy for high performance in handball ${ }^{6-9}$, coaches are concerned with structuring (directed play) the defensive return to hinder the actions of the opponents, searching for decrease their speed and recover the ball $^{10}$. These results support the aims of the defensive return by preventing the immediate counter-attack, making it difficult for the first opponents in the offensive transition ${ }^{11,15}$, as well as forcing changes or technical errors, avoiding easy opportunities to score, and organizing a cohesive defense ${ }^{18}$.

In Theme 1 two sub-themes are referring to the early defensive return, which reveals the intention to quickly organize the defensive system based on collective actions. Quickly organizing defense after the transition makes it difficult for attackers to take advantage of spaces on supported/sustained fast breaks $\mathrm{s}^{3,6,8}$. The principles of structuring the defensive return are related to the proposed directed play, in which the players' individual technical-tactical skills are valued and developed according to team guidelines (game model) $)^{19,20}$.

On the other hand, another sub-theme reinforces the guideline for the player to individually mark his direct opponent to inhibit a direct/simple fast break ${ }^{12}$ and to disturb the ball progression ${ }^{15}$ characterized by the rapid displacement of the first attackers towards the opponent's goal when the team recovers the ball ${ }^{3,10,12}$. In Figure 1, it was evident that coaches of U-16 and U-18 teams opt for guidelines regarding individualized behaviors for defensive return. The emphasis on pre-structuring individualized behaviors opposes the expectation of teams in the investment stage, such as U-18 ${ }^{29}$, and underestimates the learning possibilities of players at this stage. The begins of the defense return learning process are linked to the concepts of individual defense, providing opportunities for the simplification of the game situations, and continues with the contents linked to the responsibilities of each position in the zone defense ${ }^{12}$.

The lack of prior structure for this phase of the game was highlighted in Theme 2, and reveals the affinity of these coaches with the concept of free play ${ }^{19,20}$. Although some guidelines are established, which are not very complex, they value individualized decision-making and the development of critical thinking by players based on the situation of the game ${ }^{19}$.

The analysis of the defensive return organization revealed that $78.9 \%$ of coaches prioritize their structure (Figure 2 ). The coaches of the U-12 (87.5\%) and U-14 (90\%) teams expressed greater interest in a directed play, which reveals the concern with sports performance ${ }^{19,20}$. It is important to remember that the emphasis on sports performance in young teams can lead to 
an early sports specialization process ${ }^{13,14}$. The coaches did not emphasize the need to provide a space that values the decision making of the players in the stages of sampling (U-12) and beginning of specialization (U-14) ${ }^{14}$.

Some handball competitions in the analyzed context have rules that require the use of individual defensive systems (for U-12 teams), which emphasize direct opposition relationships ${ }^{30,31}$, and implies learning opportunities that allow players to explore defensive behaviors relevant to the contents of the defensive return. Upon losing possession of the ball, the beginners need to understand that they must follow their direct correspondent by disturbing the conduct of the ball during the defensive return $^{12,15}$. Therefore, coaches on U-12 teams should promote the concept of free play to encourage the resolution of problems that emerge from interactions with their direct opponent, and free play sounds contrary to the idea of early specialization mentioned for these teams ${ }^{32}$. It was also observed that the majority of the coaches of the U-16 and U-18 teams opted for the directed play (Figure 2), probably related to the greater demand for competitive results ${ }^{14,19,20,29}$.

García Herrero ${ }^{17}$ also suggests three main principles: a) avoid the opponent from scoring quickly on the fast break; b) decrease the opponent's speed during the extended fast break; c) regain ball possession. These principles can be guidelines for coaches to systematize the defensive return of their teams. However, the findings revealed that the coaches of the U-18 teams are concerned with promoting an unstructured defensive return, which seems contradictory to the need for high levels of specialization in handball from the U-16 teams ${ }^{29}$. From the insertion of the systematized game in zones, some relevant contents to the defensive return emerge. For the defensive return phase, the team must pay attention to the spatial distribution in a balanced way, prioritizing the most dangerous situations and the central areas $^{12}$, and a momentary organization of the defense $\mathrm{e}^{11,12}$.

Therefore, most coaches are concerned with the structured defensive return and, even with different structures, try to hinder the opponent's fast break. Most coaches structure the defensive return in teams U-12 (87.5\%) and U-14 (90\%), diverging from the need to propose favorable environments for the development of decision making and autonomy, especially in the stage of diversification (U-12). The coaches of the U-18 teams showed a high percentage of unstructured returns $(20 \%)$ when compared to the U-12 and U-14 teams, which contradicts the need for greater sports specialization at this stage. Finally, with regard to the defensive return, coaches interviewed tend to specialize in younger teams and diversify in older ones.

\section{Conclusion}

The findings showed that the simultaneous training of different teams may be leading to sports specialization procedures in the younger teams and, simultaneously, underestimating the possibilities in the older teams. Criticisms of the application of DMSP concepts (based on Canadian sport) to discuss Brazilian sports culture are pertinent, however possible similarities were observed with handball in the Brazilian context $\mathrm{t}^{29,32}$.
Some aspects related to the systematization of teams can provide opportune situations for learning relevant content for defensive return. Thus, the use of individual defensive systems allows athletes to understand the importance of following their partner when they lose control of the ball, making it difficult to counterattack. The organization of the players in zones brings different responsibilities and behaviors that allow exploring new contents of the defensive return, such as covering more dangerous zones and the momentary defensive organization.

It is reinforced that the defensive return needs to be further explored to broaden the discussions on this topic. Thus, this study provided an expanded understanding of the defensive return throughout the teaching-learning process of handball, which allows exploring the relevant content about this phase of the game. It is hoped that this study will help coaches in the teaching-learning process and contribute to the discussion of new scientific problems.

\section{References}

1. Bayer C. Editor. O ensino dos desportos colectivos. Ed. Dinalivros, Lisboa, 1994.

2. Gréhaigne J-F, Godbout P. Tactical knowledge in team sports from a constructivist and cognitivist perspective. Quest. 1995;47:490-505.

3. Menezes RP. Modelo de análise técnico-tática do jogo de handebol: necessidades perspectivas e implicações de um modelo de interpretação das situações de jogo em tempo real. Campinas. Tese [Doutorado em Biodinâmica do Movimento e Esporte] - Universidade Estadual de Campinas; 2011.

4. Menezes RP, Morato MP, Marques RFR. Estratégias de transição ofensiva e defensiva no handebol na perspectiva de treinadores experientes. J. Phys. Educ. 2016;27(1):e-2753.

5. Garganta J. Modelação táctica em jogos desportivos: a desejável cumplicidade entre pesquisa, treino e competição. In: Olhares e contextos da performance nos jogos desportivos. Porto, FADEUP; 2008. p. 108-21.

6. Bilge M. Game analysis of Olympic, World, and European Championships in men's handball. J. Hum. Kinet. 2012;35:109-18.

7. Calin R. The analysis of the efficiency of using fast breaks in female handball during the World Championship in China. 2009. Hum Mov Sci. 2010;2(1):594-9.

8. Ohnjec K, Vuleta D, Dizdar D, Milanovic D. Structural analysis of counter-attacks performed at the 2010 European handball championship for women. J. Sports Sci. 2015;8(1):7-11.

9. Möller C. "Forward Ever, Backwards Never? Current Findings to the Retraction Behaviour in Handball". 2nd EHF Scientific Conference; Vienna, Austria: EHF; 2013. p. 87-91.

10. Antón García JL. Editor. Balonmano: táctica grupal defensiva. Concepto, estructura y metodología. Granada, Grupo Editorial Universitario, 2002.

11. Estriga M. Team handball: teaching and learning steb-by-step. Portugal, Agência Nacional, 2019.

12. Antón García JL. Editor. Balonmano: fundamentos y etapas de aprendizaje. Madrid, Gymnos Editorial, 1990. 
13. Menezes RP, Marques RFR, Nunomura M. Especialização esportiva precoce e o ensino dos jogos coletivos de invasão. Movimento. 2014;20(1):351-73.

14. Côtè J, Baker J, Abernethy B. Practice and play in the development of sport expertise. In: Handbook of sport psychology. Hoboken: Wiley; 2007. p. 184-202.

15. Ehret A, Späte D, Schubert R, Roth K. Editors. Manual de handebol: treinamento de base para crianças e adolescentes. Ed. Phorte Editora, São Paulo, 2002.

16. Greco PJ, Silva SA, Greco FL. O sistema de formação e treinamento esportivo no handebol brasileiro (SFTE-HB). In: Manual de handebol: da iniciação ao alto nível.São Paulo, Phorte; 2012. p. 235-50.

17. García Herrero JA. Editor. Entrenamiento en balonmano: bases para la construcción de un proyecto de formación defensiva. Barcelona, Paidotribo, 2003.

18. IHF IHF. Teacher Guidelines https://www.ihf.info/sites/default/files/2020-03/H@S_booklet_0.pdf. 2019

19. Antón García JL. Editor. Balonmano: táctica grupal ofensiva. Concepto, estrutura y metodología. Ed. Gymnos Editorial, Madrid, 1998.

20. Feu Molina S. Organización didáctica del proceso de enseñanza-Aprendizaje para laconstrucción del juego ofensivo en balonmano. E-Balonmano. 2006;2(4):53-66.

21. Modolo F, Beltramini L, Menezes R. Revisão sistemática sobre o processo de ensino e de análise do goleiro de handebol. Cuad. Psicol. Deporte. 2018;18(3):234-251.

22. Prieto J, Gómez M, Sampaio J. A bibliometric review of the scientific production in handball.Cuad. Psicol.Deporte. $2015 ; 15(3): 145-54$.

23. Aguilar OC. Análisis de la producción científica en balonmano en las revistas de la Web of Science. E-balonmanocom: J. Sports Sci. 2014;10(2):77-88.

24. Thomas J, Nelson J, Silverman S. Editors. Research methods in physical activity. Champaign, Human Kinetics, 2015.

25. Braun V, Clarke V. Using thematic analysis in psychology. Qual. Res. Psychol. 2006;3(2):77-101.

26. Braun V, Clarcke V, Rance N. How to use thematic analysis with interview data. In: The Counselling \& Psychotherapy Research Handbook: Sage; 2014. p. 183-97.
27. Aronson J. A pragmatic view of thematic analysis. Qual. 1995;2(1):1-3.

28. Menezes R, Ramos N, Marques R, Nunomura M. Teaching handball to U-16 and U-18 women's teams: coaches' perspective on the long-term. Motriz: J. Phys. Ed.2018;24(4):e101838.

29. Santos W, Menezes R. Especialização de jogadoras de handebol a partir dos discursos de treinadores.Cuad. de Psicol. del Deporte. 2019;19(3):47-61.

30. Leonardo L, Scaglia A. Study on youth handball regulations: a documental analysis on the mandatory use of the individual defensive system in under-12 and under-14 competitions. J. Phys. Educ. 2018;29(1):e2952.

31. Menezes RP, Marques RFR, Nunomura M. Teaching handball to players under-12: the perspective of Brazilian coaches. Motriz: J. Phys. Ed.2017;23(4).

32. Menezes RP. Ensino do handebol em longo prazo: estudo a partir da opinião de treinadores. EFyC. 2018;20(2):e048.

\section{Corresponding author}

Rafael Pombo Menezes

University of Sao Paulo, School of Physical Education and Sport of Ribeirao Preto. Ave Bandeirantes, 390. Monte Alegre, Ribeirão Preto, São Paulo, Brazil. 14040907 Telephone: +55 (16) 33150349 / or +55 (16) 981124171.

Email: rafaelpombo@usp.br

Manuscript received on June 26, 2020

Manuscript accepted on September 30, 2020

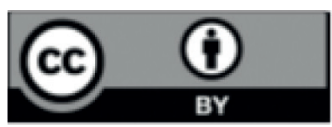

Motriz. The Journal of Physical Education. UNESP. Rio Claro, SP, Brazil - eISSN: 1980-6574 - under a license Creative Commons - Version 4.0 